\title{
THE ANNUAL MEETING IN DENVER
}

The seventy-first Annual Meeting of the American Mathematical Society was held at the Denver-Hilton Hotel in Denver, Colorado, on Tuesday through Friday, January 26-29, 1965. This meeting was in conjunction with the Annual Meeting of the Mathematical Association of America, a meeting of the Association for Symbolic Logic, and a regional meeting of the National Council for Teachers of Mathematics. The registration at these meetings was 2,056 , including 1,356 members of the Society.

The thirty-eighth Josiah Willard Gibbs Lecture was presented by Professor D. H. Lehmer of the University of California, Berkeley at 8:00 P.M. on Tuesday, January 26. Professor A. A. Albert, the president of the Society, introduced Professor Lehmer. The title of the Gibbs Lecture was Mechanized mathematics.

By invitation of the Committee to Select Hour Speakers for Annual and Summer Meetings, hour addresses were given by Professor Eugenio Calabi of the University of Pennsylvania, and by Professor David Mumford of Harvard University. Professor Calabi spoke on Curvature and differential structures on spheres. He was introduced by Professor James Eells. The title of Professor Mumford's talk was Heights of rational points and Mordell's conjecture. Professor Arthur Mattuck presided at this address.

The Cole Memorial Prize was awarded to Professor Walter Feit of Cornell University and Professor John Thompson of the University of Chicago for their joint paper Solvability of groups of odd order. The presentation was made by Professor Hans Zassenhaus, chairman of the Cole Prize Committee.

There were five sessions of selected twenty minute papers at this meeting. The first Special Session, on Tuesday, January 26 at 3:15 P.M., was arranged by Professor William Browder and consisted of five papers on Differential Topology. The authors of these papers were M. W. Hirsch, J. Milnor, J. Levine, P. E. Conner and E. E. Floyd, and W. Browder, J. Levine and G. R. Livesay. A Special Session on Differential Geometry was held on Wednesday, January 27 at 9:00 A.M. The program arranged by Professor James Eells consisted of papers by E. Feldman, T. Frankel, C. C. Hsiung, R. Sacksteder, and J. Wolf. The third Special Session was devoted to Ordinary Differential Equations. It was held on Wednesday at 2:00 P.M. The program of this session, consisting of papers by E. A. Coddington, L. Markus, J. K. Moser, S. Smale, and W. Wasow, was arranged 
by Professor Stephen P. Diliberto. A Special Session devoted to papers on Function Algebras was held on Thursday, January 28 at 3:15 P.M. It was arranged by Professor John Wermer, and consisted of papers by T. W. Gamelin and H. Rossi, K. M. Hoffman, E. A. Bishop, H. S. Bear, and Mrs. Eva Pohlmann. The last Special Session of the meeting was devoted to papers on Operator Algebras and Group Representations. Professor Richard Kadison arranged the program of this session which consisted of papers by J. M. G. Fell, C. C. Moore, E. G. Effros, A. S. Wightman, and Shôichirô Sakai. This session was given on Friday, January 29 at 3:15 P.M.

There were twenty-three sessions for contributed ten minute papers. The presiding officers at these sessions were Professor C. W. Austin, Professor R. A. Beaumont, Professor E. F. Beckenbach, Professor P. T. Church, Professor W. J. Coles, Professor J. H. Curtiss, Professor B. R. Gelbaum, Professor G. A. Gratzer, Professor Melvin Henriksen, Professor Charles Hobby, Dr. George Hufford, Professor Andrzej Hulanicki, Professor L. H. Lange, Professor M. S. Ramanujan, Professor William Ritter, Professor L. A. Rubel, Professor Arthur Sands, Professor Wolfgang Schmidt, Professor Johann Schröder, Professor Jack Segal, Professor J. L. Selfridge, Professor W. R. Utz, and Professor Gheorghe Vranceanu.

Abstracts of the papers presented at the meeting appear in the Notices of the American Mathematical Society for January 1965.

The University of Colorado, the Colorado School of Mines, and the University of Denver sponsored a tea honoring officers of the American Mathematical Society, the Mathematical Association of America, the Association for Symbolic Logic, and the National Council of Teachers of Mathematics. This event was held at 4:30 P.M. on Thursday, January 28.

The Committee on Arrangements for this meeting consisted of G. E. Bardwell and R. W. Ellingwood, Co-Chairmen, H. L. Alder, J. R. Britton, Ruth I. Hoffman, R. E. Johnson, K. L. Noble, R. S. Pierce, and G. L. Walker.

The Council met on Monday, January 25, 1965, and there was a Business Meeting of the Society at 11:00 A.M. on Tuesday, January 26.

The Secretary announced the election of the following two hundred forty-eight persons to ordinary membership in the Society:

Akeley, Edward S., Purdue University;

Aks, Stanley O., Institute of Fluid Dynamics, University of Maryland;

Alexandroff, Paul, University of Moscow, Moscow V-234, USSR;

Allen, Patrick T., Big Rivers Rural Electric Company, Henderson, Kentucky; 
Amelotti, Emil, Villanova University;

Andres, Jorge, St. Francis College;

Auer, Bruce M., Lewis Lab., National Aeronautics and Space Administration, Cleveland, Ohio;

Badenius, J. Duncan, McDonnell Aircraft, St. Louis, Missouri;

Barnett, Harold L., Lawrence Radiation Laboratory, Livermore, California;

Bazinet, Jacques, University of Sherbrooke, Sherbrooke, P. Q., Canada;

Beamer, 2nd/Lt. David M., HQ and HQ SP TRPS, Fort Eustis, Virginia;

Benintendi, Rosemary M., Monmouth College;

Benton, 1st/Lt. Stanley H., CMR No. 3, Box 2542, Offutt Air Force Base, Nebraska;

Berglund, John F., Tulane University;

Bevis, Jean H., University of Florida;

Bhatt, Suren J., The Boeing Company, Renton, Washington;

Boe, Warren J., Valparaiso University;

Brill, Elkanah H., Chevrolet Engineering Center, Warren, Michigan;

Broshi, Aviad M., Harvard University;

Burgh, Marshall J., Douglas Aircraft Company, Santa Monica, California;

Carlson, Lee A., Valparaiso University;

Castroll, Robert S., P. O. Box 485, Cooper Station P. O., New York, New York;

Celeste, Vincent R., Polytechnic Institute of Brooklyn;

Chai, Winchung A., General Precision Company, Little Falls, New Jersey;

Charmonman, Dr. Srisakdi, McMaster University, Hamilton, Ontario, Canada;

Choike, James R., Purdue University;

Cline, Neal E., University of California, Los Angeles;

Compton, Charles A., Melpar Company, Falls Church, Virginia;

Crownover, Richard M., University of Missouri;

Cutler, Doyle O., Texas Christian University;

Daly, John T., Syracuse University;

Daneluk, George Jr., Rutgers, The State University;

Davis, Stephen H., Rand Corporation, Santa Monica, California;

Davis, Thomas A., DePauw University;

Day, Jane M. (Mrs. W. R.)., University of Florida;

Day, Lavelle, International Business Machines Corporation, Ogden, Utah;

Delaney, Rev. Matthew S., Immaculate Heart College, Los Angeles, California;

Dembofsky, Thomas J., McGraw-Hill Book Company, New York, New York;

Dolnick, Gene, Chicago Teachers College;

Drake, David, National Bureau of Standards, Boulder, Colorado;

Dubinsky, Edward L., Tulane University;

Dudewicz, Edward J., Cornell University;

Dueker, Marilynn S. (Mrs. G. W.), University of Connecticut;

Duszynski, Martin Jr., University of South Carolina;

Dye, Frank R., U. S. Post Office Department, Washington, D. C.;

Edwards, Don A., Lamar State College of Technology;

Edwards, Gregg, Rice University;

Ekelund, John E., Systems Programming, Pasadena, California;

Ellentuck, Erik, Institute for Advanced Study;

Emerson, Edward P., University of Minnesota;

Enzer, Hermann, Air Force Institute of Technology, Wright-Patterson Air Force Base, Ohio;

Epstein, Kenneth J., Interphase-West, Palo Alto, California; 
Erdogan, Fazil, Lehigh University;

Estberg, Donald G., Keuka College;

Estrada, Luis, Instituto de Fisica, Ciudad University, Mexico, D. F.;

Etgen, Dr. Garret J., National Aeronautical and Space Administration, Washington, D. C.;

Evans, John W., University of California, Los Angeles;

Falbo, Clement E., Sonoma State College;

Feinberg, Irwin, Institute Blaise Pascal, Paris, France;

Fendrich, John W., College of St. Thomas;

Finkelstein, Dr. Leib, Israeli Ministry of Defense;

Firkins, John F., Gonzaga University;

Fischer, Emanuel, Adelphi University;

Forbes, Douglas R., University of Wisconsin;

Fossum, Timothy V., St. Olaf College;

Franckiewicz, Matthew M., Serra High School, McKeesport, Pennsylvania;

Frank, C. Joseph, John Wiley and Sons, New York, New York;

Frascella, William J., University of Notre Dame;

Freeman, Betty J., Randolph-Macon Woman's College;

Fuglister, Frederick J., Harvard University;

Gardner, Clifford S., Princeton University;

Gelfand, Israel M., Moscow State University, Moscow, USSR;

Georgantas, George T., Washington University;

Gibbons, Charles J., State University of Iowa;

Gilbert, John E., University of California, Berkeley;

Glickman, Elaine R., Brown University;

Goldfarb, Edwin F., City University of New York;

Goldsmith, Robert L. III., Ursinus College;

Graham, George P., Carnegie Institute of Technology;

Green, Beryl M., Oregon College of Education;

Grosz, Jason E., Courant Institute of Mathematical Sciences, New York University;

Gustafson, Helen S. (Mrs.), St. Andrews Presbyterian College;

Hall, John L. Jr., Western Electric Company, Newark, New Jersey;

Hanson, Richard J., University of Wisconsin;

Harrison, Dennis E., Tooele Board of Education, Tooele, Utah;

Harshany, Gerald P., Indiana State College;

Hazony, Dov., Case Institute of Technology;

Heap, Brian R., National Physical Laboratory, Teddington, Middlesex, England;

Herault, Daniel J., Institut Henri-Poincare, Paris, France;

Holt, John M., Collins Radio, Cedar Rapids, Iowa;

Holzman, Harold L., California State College;

Homer, John E. Jr., Wisconsin State University;

Hora, Rajinder B., Purdue University;

Howard, Edgar J., Idaho State University;

Hsiao, George Chia-Chu., Carnegie Institute of Technology;

Hudson, Francis M., McMurry College;

Hudson, Rev. Francis X., Immaculate Heart of Mary Seminary, Lenox, Massachusetts;

Hunt, Gordon C., The Boeing Company, Seattle, Washington;

Ingram, Glenn R., Montana State College;

James, Dr. Donald G., University of Auckland, Auckland, New Zealand; 
Jodeit, Max A. Jr., Rice University;

Johnson, Jackie R., Ling-Temco-Vough, Arlington, Texas;

Johnstone, John E., North Texas State University;

Jones, Rex C., Huntingdon College;

Jordan, Ferfitt, Marshall University;

Joy, William R., University of Arizona;

Just, Louis C., Argonne National Laboratory, Argonne, Illinois;

Kaack, William G., University of California, Berkeley;

Kalagian, Michael M., Morton Jr. College;

Kallick, Bruce, IIT Research Institute, Chicago, Illinois;

Kaplan, Alan, Syracuse University;

Kaul, Saroop K., University of Saskatchewan, Saskatchewan, Sask., Canada;

Keldysh, Mstislav V., Academy of Sciences, Moscow, USSR;

Kelly, May B., Wells College;

Kerr, Donald R. Jr., Lafayette College;

Kertz, George J., St. Louis University;

Kesorncam, Capt. Lert., Armed Forces Academies Preparatory School, Thailand;

Kidd, Suzanne E., Educational Testing Service, Princeton, New Jersey;

Kim, Ki Myong, Purdue University;

Koidan, Ruth (Mrs.), Catholic University of America;

Kolman, Bernard, Drexel Institute of Technology;

Krieger, Henry A., California Institute of Technology;

Kuan, Wei-Eihn, University of California, Berkeley;

Kuo, Yueh-er (Mrs. H.), University of Tennessee;

Lai, Wei, Rensselaer Polytechnic Institute;

Lash, David G., University of Kansas;

Lavrentiev, Michail A., Academy of Sciences, Novosibirsk 72, USSR;

Ledet, Mads M., Iowa State University;

Lee, Dong Hoon, Tulane University;

Lerche, Andrew O., McMurry College;

Levine, David A., Republic Aviation Corporation, East Farmingdale, New York;

Lezak, Isadore H., 4505 North Western Avenue, Chicago, Illinois;

Lin, Sue Chin, University of California, Berkeley;

Lipkin, Leonard J., University of Michigan;

Lomax, Ronald J., University of Michigan;

Lomont, John S., Polytechnic Institute of Brooklyn;

Lowry, Leslie D., Pasadena City College;

McClurg, Arline E. (Mrs. D. J.), University of Colorado;

Mackey, Thomas A., University of Colorado;

Malcev, Anatolij I., Institute of Mathematics, Academy of Sciences, Novosibirsk 72, USSR;

Malliga, Martha, Georgetown University;

Mangad, Moshe, North American Aviation, Downey, California;

Mann, Michael D., University of Southern California;

Marcinek, Thomas J., Gap Instrument Corporation, Westbury, New York;

Matson, Barbara C., Pasadena City College;

Maurice, Maarten A., University of Florida;

Meallier, André, Electricité de France, Clamart-Seine-France;

Mejia, Raymond, D. Taylor Model Basin, Washington, D. C.;

Meyers, Philip R., National Bureau of Standards, Washington, D. C.; 
Miller, John D., University of Virginia;

Mirbagheri, Ahmad, Indiana University;

Mookini, Edwin H., University of Hawaii;

Mori, Robert W., Pennsylvania State University;

Morriello, Joseph E., Lincoln Lab., Massachusetts Institute of Technology, Lexington, Massachusetts;

Morrill, John E., DePauw University;

Morris, Alfred H. Jr., U. S. Naval Weapons Laboratory, Dahlgren, Virginia;

Morrison, Barbara A. (Mrs. J. A.), College of Saint Elizabeth;

Mullin, Jennie B. (Mrs. D. W.), Newcomb College, Tulane University;

Murphy, Grattan P., St. Louis University;

Nehs, Robert M., Rice University;

Nelligan, John D., Syracuse University;

Nitzel, Willis N. Jr., Maryland School for the Blind, Baltimore, Maryland;

Oltchick, David N., The Becker Company, East Orange, New Jersey;

Ortiz-Suarez, Augusto H., Puerto Rico Nuclear Center, Caparra Heights, Puerto Rico;

Parker, Christine S. (Mrs. V. W.), Murray State College;

Pepe, James T., Massachusetts Institute of Technology;

Petrovskii, Ivan G., Moscow State University, Moscow, V-234, USSR;

Pitcher, Tom S., Lincoln Laboratory, Lexington, Massachusetts;

Plager, Max A., Roosevelt University;

Porter, James F., Hiram College;

Poschman, Kirk K., San Diego State College;

Prener, Daniel A., Leo J. Cohen Associates, Trenton, New Jersey;

Prisco, Rinaldo F., State University College at Oswego;

Quigley, Edward J., Harcourt, Brace and World, New York, New York;

Ranger, Keith B., University of Toronto;

Ratti, Jogindar S., University of Nevada;

Raymond, Ira D., University of Adelaide, Adelaide, South Australia;

Reiser, Eugene N., Division of Employment, Syracuse, New York;

Ricardo, Henry J., Yeshiva University;

Robertson, Neil, University of Waterloo, Waterloo, Ontario, Canada;

Robertson, Timothy J., University of Missouri;

Roelle, Thomas P., Illinois Institute of Technology;

Rosenbaum, Jordan T., University of Buffalo;

Rousos, Temoleon G., Ottawa Hills High School, Toledo, Ohio;

Ryan, Frank B., Rice University;

Sakurai, Akira, United States Army Engineer Waterways Experiment Station, Vicksburg, Mississippi;

Salazar, Ernest L., Goodyear Atomic, Piketon, Ohio;

Sanders, John A., Tuskegee Institute;

Sarrat, Charles F., Muebles Sarrat, El Salvador, Central America;

Schultz, Norman L., Ricker College;

Sciortino, Dr. Rosario, University of Utah;

Seidel, Marquis R., Datatrol Corporation, Silver Spring, Maryland;

Self, David C., University of Basutoland, Maseru, Sasutoland, South Africa;

Shola, Ionel S., Honeywell, Newton Highlands, Massachusetts;

Sigmon, Kermit N., University of Florida;

Silvers, Abraham, California State College at Los Angeles; 
Sise, Charles D., Oxford Paper Company, Rumford, Maine;

Sister Mary Justin Markham, St. Joseph College;

Sister Mary Rosanna Hughes, Siena College;

Skipper, Slade W., Cornell College;

Smith, Gerald F., University of Wisconsin, Milwaukee;

Smith, John M., Georgetown University;

Smith, Palmer F., Adams State College;

Smith, Sanford F., American Mathematical Society, Providence, Rhode Island;

Spiro, John G., Mellon Institute, Pittsburgh, Pennsylvania;

Stadler, Edward L., McDonnell Aircraft Corporation, St. Louis, Missouri;

Stechkin, Sergey B., Institute of Mathematics, Sophia Kovalevskaya St. 16, Sverdlovsk 49, USSR;

Steen, Lynn A., Massachusetts Institute of Technology;

Stegenga, Martin E., Louisiana State University at New Orleans;

Stevens, James W., 308 Mohawk Avenue, Norwood, Pennsylvania;

Stout, Wesley R., McDonnell Aircraft Company, Holloman Air Force Base, Alamo. gordo, New Mexico;

Strauss, Aaron, University of Wisconsin;

Stringer, Loren F., Westinghouse Electric Company, Buffalo, New York;

$\mathrm{Su}$, Chan-Hsing, Massachusetts Institute of Technology;

Suffridge, Ted J., University of Kansas;

Sullivan, Francis E., Gulf Research and Development Company, Harmonville, Pennsylvania;

Swanson, Leonard G., Portland State College;

Sykes, Zenas M., Social Security Administration, Washington, D. C.;

Taylor, Kenneth D., Army Map Service, Washington, D. C.;

Tee, Garry J., University of Lancaster, Lancaster, Lancashire, England;

Teichroew, Daniel, Case Institute of Technology;

Theall, Gary E., Tulane University;

Thomas, George A., International Business Machines Corporation, Arlington, Virginia;

Thompson, Joseph A., University of Mississippi;

Thompson, Samuel R. III, Montana State College;

Thompson, Vaughan J. Jr., 2711 Valencia Avenue, San Bernardino, California;

Tranberg, Carl C. Jr., Crane Neck Hill Road, West Newbury, Massachusetts;

Van Goethem, Pierre R., City University of New York;

Van Ryzin, John R., Argonne National Laboratory, Argonne, Illinois;

Vassalotti, Alfred G., Hofstra University;

Volk, Benjamin, Belfer Graduate School of Science, Yeshiva University;

Wadleigh, Frank R., Autonetics, Div. of North American Aviation, Anaheim, California;

Ward, Rev. William H., St. Thomas Aquinas College, Akure, Western Nigeria;

Warnock, John E., International Business Machines Corporation, Salt Lake City, Utah;

Welch, John N., Georgetown University;

Welch, John T. Jr., Goodyear Aerospace, Akron, Ohio;

Welland, Robert R., Northwestern University;

Wets, Roger J. B., Boeing Scientific Research, Seattle, Washington;

White, David E., Grand Avenue Junior High School, Bellmore, New York;

White, Virginia T. (Mrs. J. A.), Lake Washington Senior High School, Kirkland, Washington; 
Williams, Charles W., Washington and Lee University;

Wortman, Dennis H., Massachusetts Institute of Technology;

Wyman, John W., Pasadena College;

Yeaton, Joseph B., University of California, Berkeley;

Young, Ervin H., Rensselaer Polytechnic Institute;

Zablocki, Walter E., W. B. Saunders Company, Philadelphia, Pennsylvania;

Zdinak, Edward G., Virginia Military Institute;

Zund, Joseph D., University of North Carolina.

It was announced that the following had been admitted to the Society in accordance with reciprocity agreements with various mathematical organizations:

Wiskundig Genootschap te Amsterdam: Rudolf A. Hirschfeld, Carel L. Scheffer, Nicolaas A. Van Arkel.

Societe Mathematique de Belgique: Paul de Witte.

The London Mathematical Society: David Borwein, Ian J. Davies, David E. Edmunds, William J. Gilbert, John M. Howie, John R. Ringrose.

Societe de Mathematique de France: Annie (Mrs.) Besserre, Jean-Marc Braemer, Daniel Leborgne.

Deutsche Mathematiker Vereinigung: Dr. Bernd Fischer, Dieter Held, Stefan O. W. Hildebrandt, Dr. Hans Peter Langer, Wolfgang L. Walter.

Gesellschaft fiir Angewandte Mathematik und Mechanik: Guenter K. Haeuslein.

Indian Mathematical Society: Brindawan Prasad Parashar.

Unione Matematica Italiana: Roberto Conti.

Mathematical Society of Japan: Hiromi Genko, Yutaka Iei, Mitsuya Mori, Matsukawa Rieko, Keniti Sato, Shigeru Takahaski.

Polskie Towarzystwo Matematyczne: Wackaw M. Zawadowski.

Svenska Matematikersamfunder: Magnus Giertz.

The following one hundred seventy-four persons have been elected to membership in the Society on nomination of institutional members as indicated:

Andrew University: Arnold A. Dean, Edward R. Graff, Antonio Ng.

Auburn University: Kenneth H. Cranford, Albert R. Van Cleave, Jr., Bobby E. Wilder.

Austin College: Charles R. Woodrow,

Boston College: Joseph J. Dubois, Daniel E. Hughes.

University of British Columbia: William W. Armstrong, Raymond S. Booth, Bikkar S. Lalli, Robert R. Rennie, Kuldip Singh.

California State College at Fullerton: Robert L. Horvath, Clifford R. Qualls.

California State College at Long Beach: Beth M. Hooper, Eleanor D. Truitt.

University of California, Berkeley: David H. Spring.

University of California, Davis: Lloyd J. Brown, Ronald V. Canfield, Cecil E. Crawford, Stephen D. Durham, Marcel Flamm.

University of California, Riverside: Erol Barbut, John P. Lediaev, Ann A. (Mrs.) Mills.

University of California, Santa Barbara: Bonnie J. Bernhardt, Jean A. Davison, Kenneth M. Kapp, Stephen J. Pierce.

Carnegie Institute of Technology: Milton C. Chew, Jr., Jerome A. Goldstein, Donald E. 
Hall, Michael J. Lempel, Katherine K. (Mrs. D. R.) McKelvey, J. Jerry Uhl, Jr. Central Michigan University: Sam J. Brannan.

Cornell University: Frank D. Anger, David Drasin, Serge Dubuc, Michael J. Fisher,

Sol Kaufman, Gary A. Lorden, Philip Olin, Morris Orzech, Thomas A. Ryan, Jr.,

Sally R. Sievers, Robert I. Soare, Harold J. Stolberg, Steven K. Thomason,

Kenneth G. Whyburn.

Dension University: Zaven A. Karian.

De Paul University: Walter A. Pranger, Jr.

Emory University: Christine A. (Mrs. G. S.) Treash.

Fairleigh Dickinson University: Philip M. Feldstein.

Florida Presbyterian College: Michael H. Graham, Addie L. Lightner.

Fordham University: Benedict G. Scott.

George Washington University: Ludvik Janos.

Grinnell College: David A. McBlain.

Harpur College: Dennis F. Kibler.

Idaho State University: Leroy B. Beasley, David H. Brick, Jack V. Johnson, Elmo W. Killian.

University of Illinois: James A. Donaldson, Marvin C. Gaer, Richard J. Griego, Richard S. Hall, Christoph H. Hering, Richard D. Jenks, Gregory M. Kelly, Jurg Nievergelt, Donald L. Stancl, Wlodzimierz P. Stas, Junzo Tao, Catherine B. (Mrs. W. J.) Truitt, Bing K. Wong.

Illinois State University: John D. Bradburn, Daniel Chi-Kuang Chang.

Institute for Advanced Study: Cahit Arf, Tyakel S. Bhanu Murthy, Francesco Gherardelli, Gisbert F. R. Hasenjaeger, Jens Mennicke, Hung-Hsi Wu.

University of Kentucky: Donald C. Dykes, Bernard L. Madison.

Knox College: Stephen M. Baylor, Chester R. Crain, Jr., Lawrence M. Lindley.

University of Manitoba: David E. Dobbs, Robert E. Williams, Russell G. Woods.

Memorial University of Newfoundland: Hazel A. M. Pritchett, Donald E. Rideout.

University of Missouri: Thomas G. Hallam, Frank D. Johnson, Jimmie L. Nelson, Joseph S. Starr.

University of New Mexico: Larry E. Bobisud, Allan M. Carstens, J. Dalton Tarwater. North Texas State University: Robert P. Brazile, Robert H. Cranford, Mark F. Eskew. University of Notre Dame: Michael T. MacNeil.

University of Pittsburgh: David L. Powers.

Polytechnic Institute of Brooklyn: Ian N. Spatz.

Queens College: Robert N. Raffelock.

Reed College: Robert A. Lee, David F. Pincus.

University of Rochester: Robert E. Atalla, Elinor Lerner, Stephen Willard.

Rutgers, The State University: Peter A. Fowler, Clifton A. Lando, Abraham J. Ornstein, Frode Terkelsen.

Sacramento State College: James P. Conlan, Charles K. Williamson.

St. Peter's College: Francis T. Rush.

Seattle University: Darel W. Hardy.

South Dakota School of Mines: Richard W. Nau, Roger L. Opp, Allan C. Peterson.

Southern Methodist University: Jerry E. Saxton, Robert A. Shive, Jr.

Stanford University: Steven E. Bollt, Jack E. Clark, Clifford V. Comisky, Duane W. Detemple, Paul B. Goldstein, Alan C. Hindmarsh, Aggie G. Ho, David J. Kilbridge, Alan H. Larson, Herbert B. Lawson, Jr., F. Joanne McWhirter, Charles A. Micchelli, William F. Ogden, James V. Ralston, Charles M. Stanton, James D. Stewart, H. Edward Syrett, David H. Wait. 
Stephen F. Austin State College: Jasper E. Adams, John D. Stephens, Gary L. Warner. Trinity College: Peter R. Atwood, Edward W. Chapin, Jr., Dexter S. Cook.

Tulane University: George W. Crofts, William E. Meyers, John P. Riley, George E. Strecker, Donald R. Wilken.

University of Tulsa: James L. Martin, Steven L. Schluneger, Richard D. Secrest.

University of Utah: J. Cleo Kurtz, Lowell D. Loveland.

Virginia Polytechnic Institute: James F. Chew.

University of Washington: James B. Carrell, John B. Garnett, Larry E. Mansfield, Bert M. Schreiber.

Wesleyan University: Marion D. (Mrs. J.) Cohen, Robert D. Edwards.

University of Wisconsin, Milwaukee: Ronald P. Gutschow, Shu-Chung Koo.

Clemson College and Clarkson College of Technology were elected to Institutional Membership in the Society.

The following Presidential appointments were reported:

As a Committee to Recommend Recipients of the Science Medal to the President of the United States: G. A. Hedlund, Chairman, Lipman Bers.

As a Committee to Nominate Members of the Council to run for the Executive Committee: V. L. Klee, Chairman, Eugenio Calabi, P. R. Halmos.

As a Committee to Organize the Applied Mathematics Symposium on Magneto-hydrodynamics, Spring, 1965: Harold Grad, Chairman, Andrew Lenard, Marshall N. Rosenbluth, William R. Sears, Harold Weitzner.

As a Committee to Nominate Officers and Members of the Council for the 1965 election: Charles Rickart, Chairman, R. C. Buck, Raoul Bott, Deane Montgomery, Halsey Royden.

Appointments to Committees to Select Hour Speakers for the period January 1, 1965 to December 31, 1966:

To the Committee to Select Hour Speakers for Summer and Annual Meetings: R. H. Bruck.

To the Committee to Select Hour Speakers for Western Sectional Meetings: Felix Browder.

To the Committee to Select Hour Speakers for Far Western Sectional Meetings: W. G. Bade.

To the Committee to Select Hour Speakers for Southeastern Sectional Meetings: F. B. Wright.

To the Committee to Select Hour Speakers for Eastern Sectional Meetings: H. P. McKean.

As Tellers for 1964 election: Donald G. Babbitt and Robert F. Brown.

To the Joint Committee on the Graduate Program in Mathematics: C. W. Curtis. 
As Chairman of the Committee on Graduate Research and Instruction: M. L. Curtis.

To the Committee on Applied Mathematics: A. H. Taub (Chairman, 1965), H. S. Wilf.

To the Committee on Translations: Serge Lang, July 1964-July 1967.

James Glimm (replaces I. E. Segal, July 1964-65); Lawrence Markus (replaces H. Antosiewicz, July 1964-65).

As a delegate to represent the Society at the Boston Meeting of the American Statistical Association, November 27, 1964: John W. Tukey.

As a delegate to represent the Society at the inauguration of Albert H. Bowker as Chancellor of the City University of New York: Mark Kac.

As a delegate to represent the Society at the Brown University Bicentennial, September 28, 1964: Raoul Bott.

As a delegate to represent the Society at the inauguration of Dr. Howard R. Bowen as President of the State University of Iowa on December 4, 1964: J. J. L. Hinrichsen.

As a delegate to represent the Society at the inauguration of William L. Reilly as President of LeMoyne College, November 10, 1964: Erik Hemmingsen.

To represent the Society at the inauguration of John Walter Bachman as President of Wartburg College on November 11, 1964: Fred W. Lott, Jr.

As a delegate to represent the Society at the Golden Jubilee of Loyola University in Los Angeles, California: James C. Smith.

The Secretary reported that the following persons had accepted invitations to deliver hour addresses at Society Meetings: Gerhard Washnitzer at New York on February 27, 1965; James Eells at New York in April 1965; C. Ionescu Tulcea in Chicago, April 1965; Harvey Cohn at Stanford, April 24, 1965; and Ernst Straus at Stanford, April 24, 1965.

It was reported to the Council that due to the efforts of President Albert, a grant of sixty thousand dollars had been made to the Society to help finance the relocation of the Mathematical Reviews editorial offices in Ann Arbor, Michigan.

The Council recommended to the Board of Trustees that a fiveyear author index of Mathematical Reviews be prepared, to cover the years 1960-1964.

Because of the large backlog in papers accepted for the Proceedings the Council recommended to the Trustees that an additional five 
hundred pages per year be printed in the Proceedings for two years.

On the motion of the Secretary, the Council adopted the following resolution:

Dean Albert E. Meder retired on December 31, 1964, as Treasurer of the American Mathematical Society after a tenure in office of sixteen years, the longest in the Society's history. When he entered the office, the Society had some 3800 members; now the membership is over 10,000. During this period the assets of the Society increased by a factor of five and the annual expenditure by a factor of ten. The Society has entered into numerous new activities requiring imagination, shrewdness, and foresight in their financial management. All these things have resulted in an increasing degree of responsibility for the Treasurer and heavier demands on his time and energy.

The Council of the American Mathematical Society expresses its deepest gratitude to Dean Meder for his faithful performance in his office, for his skill in guiding the Society's finances through times of increasing complexity, and for his sage advice and guidance in all its affairs, and it looks forward to continuing to benefit from his services and advice as a member of the Board of Trustees.

The Business Meeting of the Society was held at 11:00 on Tuesday, January 26, 1965. President Albert presided, and some 250 members were present. The Secretary reported briefly on the affairs of the Society; in particular he reported that the Sloane Foundation had made a grant of $\$ 60,000$ to the Society to assist with moving expenses to Ann Arbor and additional operating expenses there.

The membership was then presented with two sets of changes in the by-laws which were accepted. The principal effect of the first was to increase dues from $\$ 14$ to $\$ 20$ effective in 1966. Privileges of membership include the NOTICES and the BULLETIN. The second change in the by-laws, which is to go into effect on January 2, 1966, is to change the manner in which dues are set. Under this accepted change they shall be set by the Council with the approval of the Trustees. There will be a printing of the by-laws as revised in a forthcoming edition of the BULLETIN.

During the discussion of dues it was pointed out that dues of $\$ 20$ might well discourage many worthy graduate students from joining the Society, even though nomination by Institutional Members takes care of part of the problem. Various schemes were proposed-half dues for students, and so forth. It was pointed out that the flexibility in dues under the new by-laws would make such schemes easier to put into effect and the Secretary promised to bring these suggestions to the attention of the Council and Board of Trustees. 
One member present suggested that one reason for the present large size (and therefore expense) of MATHEMATICAL REVIEWS is the excessive length of many reviews. It was proposed that a length limit might well be put on reviews. President Albert asked the member to refer this to the Editorial Board and Executive Editor of MATHEMATICAL REVIEWS.

The meeting adjourned at $11: 40$.

Los Angeles, California

JoHN W. GReEN, Secretary

R. S. Pierce, Associate Secretary

Seattle, Washington

\section{THE FEBRUARY MEETING IN NEW YORK}

The six hundred twentieth meeting of the American Mathematical Society was held at City College of the City University of New York on February 27, 1965. The registration was 110, including $106 \mathrm{mem}-$ bers of the Society.

By invitation of the Committee to Select Hour Speakers for Eastern Sectional Meetings, Professor G. Washnitzer of Princeton University addressed the Society on Tempered cohomology. Professor Arthur Sard presided and introduced the speaker.

There were three sessions for twenty one scheduled papers. The chairmen at these sessions were Professors L. S. Kennison, Russell Remage, Jr., and Selby Robinson.

Everett Pitcher Associate Secretary

Bethlehem, Pennsylvania 